\title{
USER ANALYSIS OF LIBRARY USAGE TO FULFILL INFORMATION NEEDS
}

\author{
Dyah Puspitasari Srirahayu*
}

*Program Studi Teknisi Perpustakaan, Universitas Airlangga Surabaya
Email: dyah.srirahayu@vokasi.unair.ac.id

(Submitted: 02-08-2019, Revised: 18-11-2019, Accepted: 18-11-2018)

DOI: $10.24252 /$ kah.v7i2a2

\begin{abstract}
ABSTRAK: Penelitian ini bertujuan untuk menganalisis tingkat pemanfaatan Perpustakaan Universitas Airlangga Surabaya (UNAIR). Penelitian ini merupakan penelitian deskriptif kualitatif yang menggunakan mahasiswa UNAIR sebagai sampel penelitian. Data diperoleh dari 494 responden yang diambil dengan metode incidental sampling. Untuk memastikan validnya data, ke 494 responden tersebut ialah mahasiswa yang sudah pernah berkunjung ke perpustakaan selama proses perkuliahannya, khususnya pernah mengikuti masa masa orientasi pengenalan kampus. Data dianalisis dengan menggunakan formula Yamane. Hasil penelitian ini menunjukkan bahwa tingkat pemanfaatan perpustakaan masih seperti nilai ratarata, ini ditunjukkan dengan rendahnya skor tingkat kunjungan mahasiswa (3.24\%) dan tingkat peminjaman koleksi (38.9\%).
\end{abstract}

Kata kunci: Analisis pemustaka; pemanfaatan perpustakaan; perpustakaan akademik

\section{USER ANALYSIS OF LIBRARY USAGE TO FULLFILL INFORMATION NEEDS}

ABSTRACT: This research aims to examine the usage level of Universitas Airlangga Surabaya's (UNAIR) library. This research applied a descriptive-qualitative method with the students of UNAIR Surabaya used as samples. The 494 samples taken through incidental sampling are being studied and analyzed using the Yamane formula. To obtain valid data, each student must have ever visited the library during the study in UNAIR, especially during the student orientation program. It is concluded that the usage of UNAIR library is still on the average level, it can be seen from the low number of students' visits (3.24\%) and collection borrowing (38.9\%).

Keywords: User analysis; library usage; academic library

\section{INTRODUCTION}

Library is an organization that will continue to grow and develop. Higher education institutions may not be organized well if students or lecturers are not supported by the needed resources for learning and teaching processes.

Academic libraries have wide collections ranging from books to magazines, both printed and digital. Students, in addition to receiving materials from lecturers, are also expected to keep pursuing their knowledge independently by using the learning resources facility provided by the university; the library. In addition to books, academic libraries have also provided a collection of scientific journals and magazines. Journal itself is one of the media used by researchers to disseminate the scholarly works; a scientific journal contains updated information and the latest researches compared to the book.

Librarians often measure and consider the use of resources and services through library visitors to demonstrate their effective management. The aims of those measurements can be used for taking managerial decisions about the collection wheater a collection should be purchased or not, the required personnel, the provision of services and facilities in the library. 
User surveys are useful for developing academic libraries that constantly suit their collection according to the users' needs which always constantly change. However, user surveys as the basis to make decisions regarding library upgrades, will not be optimally conducted if two very important things are not implemented (Chow, 2017). Library user surveys become a medium to collect users' data and raise awareness as well as interest in libraries. The more information gained from library users the more improvement of library services.

Universitas Airlangga (UNAIR) is one of the universities in Indonesia that that is targeted by the Indonesian government to enter the 500 World Class Universities list along with four other universities in Indonesia. UNAIR Surabaya has a library that is divided into three locations in Campus A, B and C. In addition, some faculties have also provided a reading room with resource reading materials that are suited to users' needs. The university library has stored and organized seventeen thousand titles of books and various other collections consisting of journals and students theses, starting from diploma to doctorate programs. The library has also subscribed ejournals in accordance with the fields of study that exist in UNAIR.

The aim of this research is to determine on which level does UNAIR library is used and visited, the result of this research may be worthy for stakeholders to help the library in improving their services so that it will be more helpful for the academic community.

\section{LITERATURE REVIEW}

Academic libraries are aimed at assisting the fulfillment of faculty members' goals. The purpose of the academic library is to collect, process, store, present and disseminate information to the academic community both for education, teaching, research and community service (Yuven, 2010). The word utilization comes from the word beneficial meaning or use. According to Big Indonesian Dictionary explained that the word utilization means the process, the way, the act of utilizing. The utilization of the library can mean that the utilization of all facilities in the library, whether in the form of collections, services, including in the library infrastructure. The usage of libraries can be measured through a survey that aims to find out how many users have used the library, for what reason and how the user's opinion about the library.

As mentioned before, library user surveys have proven to be a popular tool for measuring whether the library meets users' needs (Ojennus \& Kathy, 2015), as a medium for collecting user data, and helping to increase awareness and user interest for the library. More information about library users will lead to the improvement of library services.

Some library usage studies have been done by several papers. A research conducted by Daulay in 2014 in the library of Muhammadiyah University of South Tapanuli (UMTS) concluded that $78.6 \%$ of respondents visited the library once a month was more than 3 times, $80.6 \%$ of respondents used the library collections by reading on the spot and also borrowing collection, and $81,65 \%$ of respondents came to UMTS library for study purposes and adding new insights. $84.7 \%$ of respondents were dissatisfied with the circulation services, $67.4 \%$ reference services help in meeting the information needs that users need, and $61.2 \%$ of respondents answered that the collection available in the UMTS Library was inadequate.

Muflikhah in 2016 surveyed 251 students of Universitas Islam Negeri Sunan Kalijaga Yogyakarta. Her study found that the use of the library has had an effect on students' independent learning. Research focuses on the collection of a library to meet the users' needs conducted by Kayongo, Jessica, \& Clarence Helm (2010). This study showed that master students at Notre Dame (ND) were generally satisfied with the library services and library collections of Hesburgh. Asriani (2017) also conducts research on the utilization of library collections in which the results described that the utilization of library collections was less because of language constraints.

\section{RESEARCH METHODOLGY}

This research used descriptive quantitative approach to determine the level of usage in Universitas Airlangga Surabaya library. The sample population of this research is all university students who use the library. The total population was 38,869 students in 2017. Using the Yamane formula, the data error rate was $2 \%$, and the sample used in this study in the minimum was 500 respondents. The sampling technique used incidental sampling where all populations 
have the same opportunity and chances to become a sample or respondent. The respondents were UNAIR students that have visited the university library at least once during the new student orientation. The data were distributed through questionnaires, and 494 were returned. The data were analyzed with SPSS by using descriptive analysis method. The data processing for users' visit frequency and library quality assessment obtained by making averages with the formula:

Average for users' visit $=((f)$ Everyday x 6) $+((f)$ Some times a week x 5) $+((f)$ Once a week $x$ $4)+((f)$ Some times a month $\times 3)+((f)$ Once a month $\times 2)+((f)$ Some times a year $\times 1)) /$ Respondent.

The results of the calculation of the average are then categorized into three, as follows:

Table1. Average Library Users' Visit

\begin{tabular}{ll}
\hline Average & Information \\
\hline $1-2,7$ & Never \\
$2,8-4,3$ & Rare \\
$4,4-6$ & Often \\
\hline
\end{tabular}

Average library quality $=(\mathrm{f}$ Very Good $\mathrm{x} 4)+(\mathrm{f}$ Good $\mathrm{x} 3)+(\mathrm{f}$ Poor x2 $)+(\mathrm{f}$ Very Poor x1 $)) /$ Responden.

From the existing average then it can give information as follows:

Table2. Average library quality

\begin{tabular}{ll}
\hline Average & Information \\
\hline $1.00-1.75$ & Very Poor \\
$1.76-2.50$ & Poor \\
$2.51-3.25$ & Good \\
$3.26-4.00$ & Very Good \\
\hline
\end{tabular}

4. FINDINGS AND DISCUSSION

a. Demographics of Respondents

Table 3. Demographic of Respondents

\begin{tabular}{llll}
\hline Variable & & Frequency & Percentage \\
\hline Gender & Female & 363 & 73,5 \\
& Male & 131 & 26,5 \\
Age Group & $16-20$ & 334 & 66.3 \\
& $21-25$ & 150 & 29.8 \\
& $26-30$ & 4 & 0.8 \\
Level & $31-35$ & 2 & 0.4 \\
& $36-40$ & 3 & 0.4 \\
& $41-45$ & 1 & 0.2 \\
& 1 & 190 & 38,5 \\
& 2 & 105 & 21,3 \\
& 3 & 125 & 25,3 \\
& 4 & 67 & 13,6 \\
\hline
\end{tabular}


b. Student Activities in the Library

Table 4. Students' Activities in UNAIR Library

\begin{tabular}{lcc}
\hline \multicolumn{1}{c}{ Activities } & Number & Percentage \\
\hline Borrowing books & 126 & 25,5 \\
Reading library collection & 95 & 19,2 \\
Discussing & 203 & 41,1 \\
Using the Internet service & 59 & 11,9 \\
Other & 11 & 2,2 \\
Total & $\mathbf{4 9 4}$ & $\mathbf{1 0 0 , 0}$ \\
\hline
\end{tabular}

Table 5. Library Users' Visit Frequency

\begin{tabular}{lcc}
\hline \multicolumn{1}{c}{ Visit Frequency } & Frequency & Percentage \\
\hline Everyday & 15 & 3.04 \\
Some times a week & 132 & 26.72 \\
Once a week & 45 & 9.11 \\
Some times a month & 160 & 32.38 \\
Once a month & 47 & 9.51 \\
Some times a year & 95 & 19.23 \\
Total & $\mathbf{4 9 4}$ & $\mathbf{1 0 0}$ \\
Average visit & & $\mathbf{3 , 2 4}$ \\
\hline
\end{tabular}

Table 6. Learning Materials for Lectures

\begin{tabular}{lcc}
\hline \multicolumn{1}{c}{ Learning Material } & Frequency & Percentage \\
\hline Library collection & 192 & 38,9 \\
Internet & 302 & 61,1 \\
Total & $\mathbf{4 9 4}$ & $\mathbf{1 0 0}$ \\
\hline
\end{tabular}

Table 7. Collection Types for Learning Materials

\begin{tabular}{llcc}
\hline Collection & Types & Frequency & Percentage \\
\hline Text book & Printed & 203 & 41,1 \\
& Digital & 245 & 49,6 \\
Journal & Printed & 51 & 10,3 \\
& E-journal & 378 & 76,5 \\
\hline
\end{tabular}

Table 8. Internet Facility

\begin{tabular}{lcc}
\hline \multicolumn{1}{c}{ Websites } & Frequency & Percentage \\
\hline Search engine (Google) & 321 & 65,0 \\
Online journals & 125 & 25,3 \\
Blog & 11 & 2,2 \\
Organization websites & 5 & 1,0 \\
Other & 9 & 1,8 \\
Total & $\mathbf{4 9 4}$ & $\mathbf{1 0 0}$ \\
\hline
\end{tabular}




\section{c. Library Quality Assessment by Students}

Tabel 9. Library Quality Assessment by Students

\begin{tabular}{cccccc}
\hline Quality & Very Good & Good & Lacking & $\begin{array}{c}\text { Very } \\
\text { Lacking }\end{array}$ & Average \\
\hline Collection & 106 & 309 & 71 & 8 & 3,03 \\
Building & 114 & 346 & 33 & 1 & 3,16 \\
Internet & 85 & 240 & 152 & 17 & 2,80 \\
Facility & 122 & 337 & 54 & 1 & 3,26 \\
Librarian & 84 & 320 & 89 & 1 & 2,99 \\
\hline
\end{tabular}

Library users' satisfaction has long become the focus of library development. This is because libraries are built and developed to meet their users' needs. From the findings, it can be seen that the frequency of university students mostly visited the library is several times a month. However, from the actual frequency of visits, it is included in rare categories with an average visit value of 3.24 (Table 3). The development of technology communication and information has helped students to access information in ease. This affected the number of visits to libraries, in which direct visits to the library become stagnant or declining (Baihaqi, 2014) (Wulandari and Nugraha, 2011). In contrast, the level of visits to UNAIR library website was increasing.

One thing that can increase the level of visits to the library, despite many other online information media are provided, is to change the concept of libraries of "library as a place" (Wulandari, 2011). It has in line with the results of this study that Universitas Airlangga students mostly visit the library to hold a discussion. In addition, Zweizig and Dervin (in Rachel A. Fleming-Mey, 2011) mentioned that the purpose of a person going to the library is not only for reading but also to meet the individual needs of each one of them, among them is finding a comfortable place to discuss. Similar results also showed in Paul Ojennus and Kathy A. Watts's research in 2017, where Whitworth's library users provided a 24-hours learning place.

Individual learning process, regardless of a person's role, requires valid and fast the referred sources that ultimately enables the student to use the technology. The computer, laptop, or smartphone connected to the Internet can easily meet students' needs for information. Some students prefer to use technology and the internet rather than using libraries to support their learning process. Search engines, like Google, is often used by students in finding information to meet their needs (Table 6). This is due to Google is being the most widely used search engine in Indonesia (https://apjii.or.id/content/read/39/342/Hasil-Survei-Penetrasidan-Persilaku-User-Internet-Indonesia-2017).

Fry Leanna, a researcher from Brigham Young University USA in 2016 found that students at Turkish University are more likely to use Google and Wikipedia as their reference sources compared to the library and their collections, students assume that the internet is able to provide the information that they need faster and better. Riki Greenberg and Judit Bar-Ilan in 2017, in their study found that college students prefer to use Google Scholar to meet their needs. Another similar study conducted by Boger et al, related to the impact of library information literacy class in four-year students' information-seeking behavior in 2015. He also pointed out that students often seek information through Google compared to the library database.

The results of this study also show similar points where $61.1 \%$ of the students use the internet to seek learning materials (Table 4). Besides that students also tend to use textbooks and journals in digital form (Table 5) to fulfill their obligations as students. The results of the survey above are emphasized by Latimer (in Paul Ojennus and Kathy A. Watts, 2017) that there was a factor that leads to the change of library function in the last 20 years, in which the increasing availability of electronic resources, a shift in the balance between print resources to electronics, all leads to technological advancement. This makes library users' interest towards to printed media becomes reduced and decreased. The same results are also obtained from Kayongo, Jessica, \& Clarence Helm (2010). They found that the University of Notre Dame students $(62.8 \%)$ prefer to use remote access to obtain electronic references for their research. 
Halling and Carrigan (Ojennus \& Kathy, 2017) mention that in addition to seating, booths, study desks, and quite study environment that was requested the librarians at the Library of Medical Studies at Texas A \& M University, they also request additional computers or additional enhancements to technology tools.

The decline in the use of library collections in Universitas Airlangga, as well as cultural changes, is also due to the belief that the internet resources tend to be able to provide the information they need compared to coming and sitting at the class face-to-face with the lecturers. The up to date information and references also become of the reasons why students are shifting to online resources. The research conducted by Jamaluddin, 2017, showed how the library users of Universitas Muhammadiyah Makassar are influenced the collection availability. Its study indicated that the availability of collections has affected user visits in the Library. However, from the results of a research conducted by Leanna (2016) showed that University of Turkey students who have received literacy training have shown a significant improvement in their interest in library usage and sources rather than students who did not receive literacy training. Maxwell (in Jessica Kayongo and Clarence Helm, 2010) found that very few librarians interact with the users. This is a challenge for librarians to get closer and provide literacy training to the users.

Feedback about the library quality were also gathered in this study. Table 7 shows the overall quality of the library. The highest quality value is the facilities provided by the library to its users. However, it still needs to be improved because one of the things that will interest potential library users is how the library may become a convenient place for their activities after classes. The lowest value for the quality in the library is the Internet. In addition, to good space for discussion, current users also require a better internet connection to support their study. Table 2 shows that users come to the library to use the Internet. Although it seems that students visit the library only to use the space and room along with the internet instead of reading, it can become the first small steps to properly introduce the function of the library. Literacy activities can continue to be developed by introducing the sources of information and collection owned by the library that may have not been widely known by the students yet. There should also be a book promotion through library announcements conducted by the review center that will keep the users informed of new and good library collections.

\section{CONCLUSION}

The usage of Universitas Airlangga Library can still be considered as average, this can be seen from the level of visits to the library that is still rare with the value of 3.24 and the low percentage of students who use the library collections (38.9\%). Based on the study, Universitas Airlangga library can still be improved because many potential users may attract to use dan visit the library due to the high rating given by the majority of students who regard the library qualities and facilities as good. The library needs more attention in their management, in which librarians and other staffs need to keep improving the quality of the library. This needs to be done so that the library will be able to receive a good image in the eyes of students and users, and can cause them to be more engaged to visit the library.

\section{REFERENCES}

Asriani. (2017). Analisis Pemanfaatan Koleksi Pojok India di UPT Perpustakaan Universitas Negeri Makassar, Thesis, Univeristas Alaudidin : Makassar

Baihaqi, A. (2014). Retrieved from http://www.koran-o.com/2014/solopolitan/budayamembacaperpusda-kian-sepi-pengunjung-58765

Boger, T. S., et all. (2015). The impact of library information literacy classes on first-year undergraduate students' search behaviour. Journal of Information Literacy. Vol 9 (1) Hal 34-46

Chow, J. (2017). Realising the potential of user surveys for improving academic libraries: The case of St John's College, Cambridge. Journal of Librarianship and Information Science, 42. 1-13. https://doi.org/10.1177/0961000617732379 
Daulay, I. A. (2014). Analisis Pemanfaatan Perpustakaan dalam Memenuhi Kebutuhan Informasi Pengguna Perpustakaan Universitas Muhammadiyah Tapanuli Selatan, Thesis, Universitas Sumatera Utara: Sumatera Utara

Fleming-May, \& Rachel A. (2011). What is library use? Facets of concept and a typology of its application in the literature of library and information science. JSTOR Journals. Vol. 81 (3) Hal. 297-320

Leanna, F. (2016). Students attitudes towards library usage and sources at a Turkish university. International Federations of Library Associations and Institutions 2016, 42, 126-133. DOI: $10.1177 / 0340035216645370$

Greenberg, R., \& Bar-Ilan, J. (2016). Library metrics - studying academic users' informa- tion retrieval behavior: A case study of an Israeli university library. Sage Journals. Vol. 49 (4) Hal 454-467

Kayongo, J., \& Helm, C. (2010). Graduate students and the library: A survey of research practices and library use at the University of Notre Dame. JSTOR Journals. Vol. 49 (4) Hal 341-349

Ojennus, P., \& Watts, K. A. (2017). User preferences and library space at Whitworth University Library. Sage Journals. Vol. 49 (3) Hal 320-334

Muflikhah, U. (2016). Pengaruh Pemanfaatan Perpustkaan Terhadap Kemandirian Belajar Mahasiswa UIN Sunan Kalijaga Yogyakarta, Thesis, Universitas Islam Negeri Sunan Kalijaga: Yogyakarta Indonesia

Jamaluddin, N. (2017). Pengaruh Ketersediaan Koleksi Terhadap Kunjungan Pemustaka di Perpustakaan Universitas Muhammadiyah Makassar. Tesis. Universitas Muhammadiyah: Makassar Indonesia alauddin.ac.id/4272/1/NURLAELI\%20JAMALUDDIN.pdf

Wulandari, D. (2011). Mengembangkan Perpustakaan Sejalan Dengan Kebutuhan Net Generation. Visi Pustaka, 13(2), 16-24. 